\title{
Feeding Revolution: The Black Panther Party and the Politics of Food
}

\author{
By Mary Potorti
}

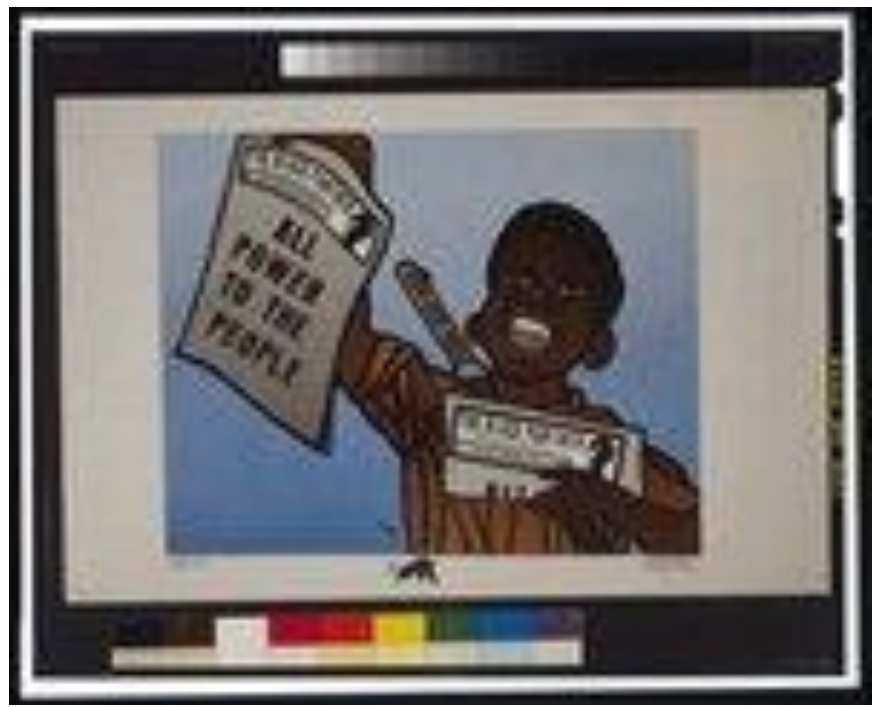

COURTESY OF LIBRARY OF CONGRESS

First you have free breakfasts,

then you have free medical care,

then you have free bus rides,

and soon you have FREEDOM!

-Fred Hampton, Deputy Chairman,

Black Panther Party, Illinois

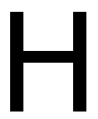

aving studied as an undergraduate under Warren Belasco, a pioneer in the field of food studies, I have for years been conscious of the politics behind food production and consumption. In my own research and teaching, however, I returned to food studies not with an interest in food, per se, but as a means of investigating structures and systems of power and inequality. Historical moments that transformed my own insular undergraduate worldview-namely, the black freedom struggle, the Vietnam War, and the emergence of second wave feminism and gay liberation-sometimes barely registered with my students, many of whom saw little connection between their own fields of study in 
communications or the health sciences and current issues involving race relations, capitalism, gender inequality, gay rights, or international affairs. After two years meandering through stacks of literature about the black freedom struggle in search of a new topic or innovative approach suitable for a dissertation, I attended a fascinating presentation by Alondra Nelson in 2011 about the Black Panther Party's efforts to combat medical discrimination. I began to consider the potential of reaching media- and science-minded students by de-emphasizing key historical figures and events and instead focusing on the human body itself as a site of social and political struggle. ${ }^{1}$ Food, I came to realize, is often a weapon in these battles.

The dynamics and tensions of agency and coercion, autonomy and oppression, at play in the global food system-manifested in myriad recent controversies surrounding the Farm Bill, food stamps, GMOs, obesity, healthcare, hunger, school lunch programs, food waste, food deserts, food safety, farmers' markets, fast food wages, globalization, and slave labor around the worlddirectly reflect and implicate historical patterns of marginalization and oppression. Current realities have historical roots, and historical campaigns and programs have modern-day reverberations. In an age where student activism largely occurs in cyberspace, if anywhere, many undergraduates see little point in attempting to challenge or even question systems of power when 1) the target is so diffuse, and 2) prospects for immediate, tangible gains are dim, to say the least. Relatively recent stories, for example, about fast food workers striking for a \$15 minimum wage or Walmart's revealing move to place bins for customers to donate food items to help feed the company's own employees, make clear that food insecurity persists. But many voice surprise, even disgust, with the notion that McDonald's employees "deserve" a living wage or believe that a carefully-constructed hunger safety net will catch those who fall through the cracks. Rarely have my students articulated an impassioned belief that change can be effected from the grassroots. In U.S. history and food studies courses, I often turn to the Black Panther Party and its food service programs to raise questions about how "poor people's movements" develop, how tactics and strategies develop, and, in the words of Frances Fox Piven and Richard A. Cloward, "why they succeed" and "how they fail."

\section{Speaking of the newly renamed "Food for Peace" program in 1961, President John F. Kennedy highlighted a reality that many African Americans and civil rights activists already acknowledged. "Food is strength," Kennedy proclaimed, "and food is peace, and food is freedom, and food is a helping to people around the world whose good will and friendship we want."}

Resisting the object-centered lens of much food studies work, Kyla Wazana Tompkins's Racial Indigestion (2012) calls for closer examination of "texts and [historical] moments during which acts of eating cultivate political subjects by fusing the social with the biological, by imaginatively shaping the matter we experience as body and self." ${ }^{3}$ Following her lead, I frame my undergraduate food course, "The Politics of Food," around questions of identity and agency, access and accountability, health and sustainability, rather than commodities, flavor principles, etiquette, or culinary innovations. Though certainly the material delights of food are laden with cultural significances that reflect and reinforce social dynamics and political relationships, eating as an act itself, the meaning of which primarily stems from the identity of the eating subject rather than the eaten object, speaks to the reality that some have far greater access to "good" food than others. The Black Panther food programs represent an opportunity to approach food less as a forum of cultural and community expression than as a tool for political mobilization. As a historical case study, the Panther food programs offer several useful angles for classroom interrogation of hunger and emergency food relief specifically, as well as struggles for liberation and movements for social change more broadly. Their message remains relevant today, or as The Black Panther newspaper proclaimed in March 1969, "Hunger is one of the means of oppression and it must be halted. ${ }^{4}$

\section{Historical Context}

Speaking of the newly renamed "Food for Peace" program in 1961, President John F. Kennedy highlighted a reality that many African Americans and civil rights activists already acknowledged. "Food is strength," Kennedy proclaimed, "and food is peace, and food is freedom, and food is a helping to people around the world whose good will and friendship we want." ${ }^{5}$ In light of the rediscovery of poverty in the United States, initiated by Edward R. Murrow's documentary treatment of the plight of migrant farm workers in 1960's Harvest of Shame, Kennedy's pronouncement would prove both profoundly insightful and painfully short-sighted. Amidst the prosperity and abundance of postwar America, the persistence and pervasiveness of poverty-and its most pressing symptom, hunger-grew both more pronounced and less palatable. Despite the lofty rhetoric of Lyndon Johnson's War on Poverty, tellingly launched on the porch of white Kentucky sharecroppers in 1964, tangible gains for America's poor were piecemeal, politically-contentious, racially-charged, and ultimately fleeting. The intertwining of racial oppression and class inequality, which has characterized American history since slavery, expanded the implications of poverty beyond issues of material welfare, fostering a crippling physical and psychological condition that diminished prospects of justice and freedom for the poor. Religious charities like those run by the Catholic Church and mutual aid societies formed by immigrant communities have deep roots in American history. While they provided needed services, they worked toward no long-term solutions. During the Great Depression, hunger amidst 
surplus became a national scandal, as the government paid farmers to overproduce while millions continued to starve. ${ }^{6}$ During this time the communist Alabama Sharecroppers' Union worked to mobilize a racially-conscious class-based movement to secure rights for tenant farmers, recognizing the connection between the race of most Alabama sharecroppers and the biases of a system that kept hardworking families in an intergenerational cycle of debt. Decades later in neighboring Mississippi, the Student Nonviolent Coordinating Committee (SNCC) quickly realized that civil rights work in the poorest counties of the Delta would be pointless if people were too paralyzed by hunger and food insecurity to move. In fact, the long black freedom struggle has repeatedly underscored the cultural and political significance of food, explicitly calling attention to interlocking structures of racism and social inequality embedded in the politics and culture of food. Conceptualizing food as a site of conscious and concerted social activism calls attention to the problematic interstices of the "racialized political economy of food production and distribution" and the "cultural politics of food consumption" in the United States. ${ }^{7}$ Offering a new vantage point from which to scrutinize and formulate questions about racial equality and social justice, food studies encourages a more inclusive, expansive understanding of the black freedom struggle. The lens of food justice and what Tompkins has termed "critical eating studies" in particular requires a broadening of the term "activist" to include all those seeking to resist systems of oppression in efforts to improve their daily lives. It also mandates a revision of more conventional definitions of "freedom," most of which have focused on integration and voting rights, by illuminating the essential role of food in both the symbolic politics and practical agenda of movement activists.

\section{This tactical progression from guns to butter was not reformist or counterrevolutionary, as critics like Panther leader Eldridge Cleaver charged, but instead represented a flexible and logical response to official efforts to thwart the Party's growth and influence.}

The Black Panther Party, a community-based organization headquartered in Oakland, California dedicated to radical politics, armed self-defense, and racial self-determination, advanced one of the most devastating, forceful, and potentially revolutionary critiques of the American food system to emerge during this decade of sweeping social change. In 1969, Huey P. Newton, Panther co-founder and Minister of Defense, mandated that all Party chapters nationwide institute a Free Breakfast for Children Program. Only recently released from jail after his acquittal in a long and highly-publicized trial for murdering a police officer, Newton and his Party had become infamous for their militant efforts to "police the police" via community patrols by young black men in leather jackets and berets openly bearing loaded guns. This new directive established the first of the Party's much-celebrated
"Survival Programs," which provided free goods and services to the urban poor. The most popular and, oddly, the most controversial of these programs were centered on food.

Despite their infamously militant tactics, the Panthers, and Newton in particular, contended that combating police brutality and racial violence was but one dimension of their broader vision of black liberation-a vision rooted in demands for "freedom" and the "power to determine the destiny of our Black Community." "Interested primarily in educating and revolutionizing the community," Newton later explained, "we needed to get their attention and give them something to identify with." ${ }^{9}$ The tenth point of the Party platform encapsulated the tangible gains it sought for America's "black colonial subjects," declaring, "We want land, bread, housing, education, clothing, justice, and peace." Struggles for land and housing required long-term legal and economic strategizing, while major reforms of the urban education system would require skillful reorganization and enormous financial investment, all with no immediate payout. Though certainly apparent in the physical deterioration of the nation's cities, the human toll of "the urban crisis" was most palpable in the daily suffering of the hungry poor. Therefore, while African Americans worked toward long-range goals of "freedom," "justice," and "peace," the Party began organizing around the basics of bread.

This tactical progression from guns to butter was not reformist or counterrevolutionary, as critics like Panther leader Eldridge Cleaver charged, but instead represented a flexible and logical response to official efforts to thwart the Party's growth and influence. ${ }^{10}$ In this vein, the survival programs were broadly "designed to underline the injustices of American capitalism and stimulate the Black masses into revolting against the American government" and, in doing so, to "lay the groundwork for the insurrection" necessary to bring about a new racial order. ${ }^{11}$ The interracial, cross-cultural, and politically innovative alliances the Party forged were both possible and momentarily effective because the Panthers, and particularly Party co-founder and political philosopher Huey Newton, interpreted the world at the end of the 1960s in a way that made sense to a variety of suffering peoples who were, if not ripe for radicalization, sympathetic to the demands and tactics of militants in America's streets.

Panther food programs, which began with a single breakfast program in Oakland, exploded to over 36 sites nationwide by 1971 . Their food work also included free food programs and spectacular "Survival Conferences" in the Spring of 1972, in which free groceries were a featured attraction. These programs relied entirely on donations from community members, local churches, and most importantly from neighborhood businesses and grocery chains. While the labor needed to make and serve the food each morning was voluntary, provisioning foodstuffs and other supplies was often a matter of manipulation, even coercion. Party members, parents, and sometimes the children themselves solicited donations from local grocery stores and businesses. While some willingly contributed, others, including chains such as Safeway and Mayfair and 
independent operations like black-owned Bill Boyette's liquors, refused to do so. In these cases, the Party counted not on the goodwill of local businesses so much as their fear of economic retribution. The politics of the breakfast program thus underscored the division between the haves and have-nots. Joshua Bloom and Waldo E. Martin, Jr. note, "The Panthers drew a line dividing the world in two." ${ }^{12}$ Indeed, it became easier for people to understand the persistence of hunger, for example, when a store such as Safeway could be castigated for withholding food from needy children. Though widespread hunger has diffuse points of origin, Panther food programs and food politics devised concrete locations and sites for the poor and working classes to challenge capitalists who profited from the community without giving back. The Party newspaper regularly listed stores that refused to participate or contribute to their cause. In April 1969, the Panther chided "the avaricious businessmen that pinch selfishly a little to the program. We say that this is not enough, especially from those that thrive off of the Black Community like leeches." The Party not only charged "avaricious businessmen" with perpetuating hunger by overcharging for food commodities but also demanded that those businesses be part of the solution or face swift economic reprisals. As a result, the Party fostered an ideology of hunger predicated on the belief that capitalism was responsible for the people's suffering, but that ironically also relied on the imperatives of capitalism to get businesses in line with their program. In this way, the breakfast programs had the potential to awaken the revolutionary consciousness of the people to see the interrelatedness of capitalism, social stratification, and their own material deprivation and political marginalization. Despite some objections to these practices, the breakfast programs were a runaway success.

The practical benefits of free breakfasts were great. As The Black Panther regularly emphasized, a morning meal worked to silence the hunger pains of black youth that so often incapacitated them during school hours. One Party member asked her comrades, "How can a person be expected to pay attention and learn about history, math, science and other subjects that are abstract to his reality when his mind is concentrating on a very real and concrete problem? Where is the next meal coming from?" ${ }^{13}$ The connection between undernourished bodies and underdeveloped minds was plain: Children must be fed each morning if they were to feed their minds at school during the day, to establish fundamental skills in math and reading necessary not only for socio-economic mobility but for political mobilization as well.

Certainly Panther food programs operated as vital emergency measures to get food to the hungry and nutrients to the malnourished. But that was only the beginning. David Hilliard acknowledged that food "serves a double purpose, providing sustenance but also functioning as an organizing tool." ${ }^{14}$ As Newton later wrote, the survival programs "were designed to help the people survive until their consciousness is raised, which is only the first step in the revolution to produce a new America....In themselves they do not change social conditions, but they are life-saving vehicles until conditions change." ${ }^{15}$ The practical necessity of the food programs, and the clear and vital interest they aroused in the Party among residents of Oakland and other major cities, sparked a series of foodcentered political campaigns aiming not only to improve the daily lives of the hungry, but to address structural inequalities that served to keep African Americans and other economically and politically oppressed groups divided and weak.

\section{Panther food programs, which began with a single breakfast program in Oakland, exploded to over 36 sites nationwide by 1971.}

Four months into the first program, Newsweek quoted a California police officer who asked, "How can anyone be against feeding kids?" The skepticism, resistance, and outright opposition the programs encountered, however, made clear that many, especially those in positions of authority, were opposed to feeding some kids, and adamantly so. The extent of police harassment of the Party's breakfast programs nationwide and the intricate work of the FBI's Counterintelligence Program (COINTELPRO) to "expose, disrupt, misdirect, discredit, or otherwise neutralize the activities" of the Panthers (among other black organizations) demonstrated that officials at the local and federal level perceived the food programs to be a multivalent threat. Panther Elaine Brown, who spearheaded the establishment of a Panther free breakfast program in Los Angeles, surmised that "[t]he success of the Panther free breakfast programs for the poor...as much as Panther guns triggered [FBI director] J. Edgar Hoover's targeting of the party for the most massive and violent FBI assault ever committed." ${ }^{16}$ According to Bureau records, one FBI head instructed agents in San Francisco, "...The BPP is not engaged in the 'Breakfast for Children' program for humanitarian reasons [but for others], including their efforts to create an image of civility, assume community control of Negroes, and to fill adolescent children with their insidious poison." ${ }^{17}$ Subsequent COINTELPRO efforts to impede operations included harassment of church leaders who hosted daily meals, questioning and occasional arrest of youth and Party members who attended or volunteered, often frivolous citations from the public health department, and sometimes physical destruction of the food itself. In its more devious moments, the FBI circulated rumors in San Francisco that the breakfasts were unsafe because "various personnel in national headquarters...are infected with venereal disease" and in Raleigh-Durham that the nephew of the chief breakfast organizer was a pedophile who physically abused the children in attendance. ${ }^{18}$ According to Panther Chief of Staff David Hilliard, who oversaw the expansion of Panther service work, "Police raided the Breakfast for Children Program, ransacked food storage facilities, destroyed kitchen equipment, and attempted to disrupt relations between the Black Panthers and local business owners and community advocates, whose contributions made the programs possible. ${ }^{19}$ But why? The 
extent to which government operatives worked to undermine these food programs suggests that they, too, understood what was at stake in permitting communities to see the direct connection between strong bodies and strong minds, between healthy children and healthy communities, between food and freedom.

Indeed, many heralded the transformative potential of the survival programs, asserting that for true freedom to be possible, the material essentials of life must be free of cost. The Marxist politics of Newton and his followers, of course, lay at the root of this worldview, which declared that freedom and capitalism by definition could not coexist. "Capitalism is what put black people in slavery," the Black Panther declared in March 1969. "Capitalism is why black people can't get decent housing and capitalism is why there are so many hungry children in the black communities of America today." 20 But the survival programs went further, showing not merely what was wrong with capitalism but also how socialism could work. Seale made the connection obvious: "Once the people see a socialistic program is valuable to them they won't throw it away. By practicing socialism they learn it better. ${ }^{21}$

\section{Many heralded the transformative potential of the survival programs, asserting that for true freedom to be possible, the material essentials of life must be free of cost.}

Viewing the late Sixties as a moment truly ripe for revolution, Newton and Seale sought to raise the awareness of the oppressed of all races to see the systemic forces that worked to perpetuate their daily struggles against hunger, malnourishment, ill health, poor housing, illiteracy, and a host of other social barriers. If, as Newton insisted, the Party's survival programs were merely a prelude to an armed overthrow of the capitalist system, the food programs played a vital part by addressing the need for bread-a need that has been at the root of people's liberation struggles throughout history.

\section{In the Classroom}

The healthy state of Black Power studies and Black Panther scholarship in recent years has produced several important and accessible histories of the Party's formation, ideology, political evolution, and social programs, several of which are easy to excerpt and accessible to undergraduates. Historian Donna Jean Murch frames her study, Living for the City (2010), around the experiences of southern blacks who migrated to California in search of better employment and the mobility promised by a strong public education system. Chapters titled "Survival Pending Revolution" and "A Chicken in Every Bag" speak directly to Panther Survival Programs, arguing that they were unique and influential not because the Panthers were the only group providing such services to the poor (they weren't), but because Panther programs "politiciz[ed] welfare rights by showing a coordinated national effort that highlighted the Party's successes and the government's failures." 22 More recently, Joshua Bloom and Waldo E. Martin, Jr. argue in Race Against Empire, a political history of the Panthers, that this progression from armed community defense to service programs was not reformist or counterrevolutionary, as some contemporaries charged, but instead a flexible and logical response to official efforts to thwart the Party's growth and influence. In the authors' estimation, the unifying thread and the centerpiece of Panther political philosophy was a "nondogmatic, Marxinflected anti-imperialis[t]" worldview-an incisive, timely critique of class and power in the United States. ${ }^{23}$ Bloom and Martin posit that Panther politics was undergirded by a belief that black Americans and other disenfranchised groups were, in effect, internal colonies of the United States. Examining the psychological effects of this "ghettoization" on individual and communal development, Black Against Empire deftly situates the daily (lowercase " $p$ ") politics of survival in poor urban black communities within the context of the international (capital " $P$ ") political struggles of subjugated nations and peoples against forces of global imperialism. By this account, Panther politics acknowledged the international dimensions of systems defining the rights of people not only in their relation to state power but in the political dynamics governing nations' relationships to each other as well. As this work proves, the Panthers were not insular and impulsive but instead largely collaborative and deliberate-qualities that inspired followers and created coalitions. Both works can serve well to provide historical context and a political lens through which to interpret Panther food politics.

Viewing the late Sixties as a
moment truly ripe for revolution,
Newton and Seale sought to raise
the awareness of the oppressed of
all races to see the systemic forces
that worked to perpetuate their
daily struggles against hunger,
malnourishment, ill health, poor
housing, illiteracy, and a host of
other social barriers.

I often frame conversation about the Black Panther Survival Programs with a fifteen-minute clip from The Black Power Mixtape, 1967-1975 (dir. Goran Olsson, 2011). ${ }^{24}$ This documentary provides a concise, compelling introduction to the black freedom struggle, theories of Black Power and political radicalism, and leaders and programs of the Black Panthers, highlighting the interplay between poverty, physical vulnerability, and political disfranchisement. The film is pieced together from recently discovered archival footage shot by a Swedish film crew during the late 1960 s and early 1970s, voice-over commentary from historical personalities including Kathleen Cleaver and Angela Davis, and reflections and childhood memories from hip hop artists like Talib Kweli and Erykah Badu. Rather than show the entire film (which is certainly worth the class time), I begin about twenty-five 
minutes into the film with a sequence capturing a single black mother in New York City as she struggles to get her ten children roused and ready for school. The narrator points out that there is not enough food for all of the children to eat breakfast (which on this day is only dry cereal), while the camera frames the inadequacies of the living space. The sequence then frames a Panther liberation school, where children sing about the coming revolution; a female Panther leader affirming to foreign reporters the Panthers' willingness to die or go to jail for the cause; and scenes from an early morning breakfast program. Grappling with these images urges students to see that hunger and malnourishment are symptoms of a sick social system, beset by the harmful contradictions of capitalism.

Other primary sources about the Panther food programs abound, including Party literature, news stories, interviews, oral histories, and autobiographies. Moreover, The Black Panther newspaper is itself a veritable archive of Panther rhetoric and imagery, including articles by central party leadership, reports from local chapters, ads requesting aid and donations, letters from friendly and hostile readers, photos of Panther events, and the masterful artwork of Minister of Culture Emory Douglas. Douglas's images are particularly fruitful in the classroom. Depicting the black urban poor in humanizing, sympathetic, even heroic terms, Douglas's cover art directly connects daily struggles for food, clothing, work, shelter, and peace of mind to the Party's broader revolutionary Marxist vision, often while demonizing specific politicians and figures in the local community. For example, during a BPPorchestrated boycott of Boyette's Liquor Store, Douglas portrayed Bill Boyette as an "honorary Klansman" for his refusal to "treat the people to a piece of bread" by pledging a regular donation to the breakfast program.

\section{Students often sympathize with the Panther's strategy of mobilizing the poor through social service work. However, they frequently object to the tactics used to achieve these ends.}

Sources offering reactionary perspectives are tellingly plentiful as well. Internal documents from the FBI's Counterintelligence Program (COINTELPRO) provide a particularly stark contrast. Numerous internal memos to and from FBI director J. Edgar Hoover reveal that federal officials perceived the food and other survival programs as a devious, highly effective tactic to divert media scrutiny and win over those living in the nation's urban ghettoes. Even more shocking to students, the documents often detail specific instructions or reports about how to infiltrate the Party and sabotage its operations, tactics that historians largely agree succeeded in fracturing party leadership and fueling internecine feuds and intra-racial street violence. Many students express disbelief that the United States government would go to such extremes to impede what many see as an objective social goodfeeding the hungry. The language of these documents makes plain that those in positions of authority recognized the appeal of free food programs and realized that in order to maintain the status quo, such programs must be quashed. One way this was accomplished was by establishing comparable government-run programs, namely free breakfast programs inside public schools. This realization itself is instructive, urging students to question the motives of government officials and to entertain the possibility that problems like hunger and widespread poverty are not inevitable, but the result of systematic biases that agents of power often have a vested interest in protecting.

Sociologist Janet Poppendieck's work on hunger and emergency food services provides crucial historical grounding and theoretical framing for this discussion, while placing these short-lived programs in conversation with food politics at the turn of the $21^{\text {st }}$ century. ${ }^{25}$ The Panthers close practical alliance with community churches, which often housed the free breakfasts, fosters easy comparisons between the Survival Programs and the charity work often conducted by religious organizations. But in contrast to many church-run soup kitchens or food pantries that provide an outlet for congregants to act charitably toward their less fortunate brethren, the Panthers were not driven by charitable aspirations, which Poppendieck points out often actually serve to depoliticize hunger. Poppendieck writes that charitable "[f]ood programs not only make the well fed feel better, they reassure us that no one will starve, even if the nation ends welfare and cuts gaping holes in the food stamp safety net." ${ }^{26}$ Even worse than the moral complacency fostered by "sweet charity," Poppendieck argues that emergency food assistance programs and infrastructure renderour society vulnerable to token solutions that simply link together complementary symptoms without disturbing the underlying structural problems." 27 In striking contrast, the Panthers' food programs and anti-hunger politics worked to address the persistence of food insecurity by dramatizing its political roots and implications. Though the Panthers targeted the graphic problem of hunger, it was only the beginning of their multi-faceted program for community survival. Paired with a host of other programs to address needs for food, clothing, shelter, shoes, and meaningful education, Panther food programs reflected Poppendieck's assertion "that the food portion of this complex web of human needs can [not] be met independently of the rest." ${ }^{28}$ The Panthers recognized that hunger could not be addressed in a vacuum and that racial inequality could not be addressed without tackling socioeconomic equality.

The historical moment offers several pedagogical opportunities to engage with issues of poverty, racial inequality, and social movements more broadly. First, why did the Panthers become involved with these Survival Programs? Where and how did they see a need and what payout did they seek from dedicating enormous resources to this work? Some students, mirroring the language of contemporary Panther critics and early Panther scholarship, express skepticism that the food programs were actually driven by humanitarianism, raising another important question. Was emergency food aid a tactical 
move, or did Party members really view this as the ground floor of the revolution they sought?

Indeed, students often sympathize with the Panther's strategy of mobilizing the poor through social service work. However, they frequently object to the tactics used to achieve these ends. Film clips from breakfast programs portray children repeating after a male Panther, "All power to the people...Free all political prisoners. Right on!" These scenes intrigue and sometimes disturb students, who quickly formulate revealing inquiries. Were the Panthers really any different from the federal officials and local programs they criticized? Are all social programs inherently disempowering? Is service work without agenda really possible? And if, as I generally contend at the beginning of the lesson, food is freedom and food is control, did the Panthers not also manipulate the hungry, using their growling stomachs to pull them into their program? Does it matter, I ask? Can't the end justify the means, especially when the means entail that fewer children went to school on an empty stomach? Is this really coercion, as some propose? Or is this simply how "poor people's movements"-and many other social movements, for that matter-operate?

\section{Frances Fox Piven and Richard A. Cloward's classic work, Poor People's Movements: Why They Succeed, How They Fail (1977), helps address some of these questions. ${ }^{29}$ Reflecting on specific class-based movements during the $20^{\text {th }}$ century, the authors theorize the interplay between state power, historical circumstances, leadership personalities, organizational structures, and the demands and outcomes of social movements on behalf of the poor.}

Frances Fox Piven and Richard A. Cloward's classic work, Poor People's Movements: Why They Succeed, How They Fail (1977), helps address some of these questions. ${ }^{30}$ Reflecting on specific class-based movements during the $20^{\text {th }}$ century, the authors theorize the interplay between state power, historical circumstances, leadership personalities, organizational structures, and the demands and outcomes of social movements on behalf of the poor. Piven and Cloward affirm the need to approach historical moments with objectivity and respect for the reasoning of movement leaders. They contend that "so long as lowerclass groups abided by the norms governing the electoralrepresentative system, they would have little influence.... $[\mathrm{P}]$ rotest tactics which defied political norms were not simply the recourse of troublemakers and fools. For the poor, they were the only recourse." ${ }^{31}$ From this vantage, the criticism and backlash elicited by the Panther food programs seems inevitable. For as Piven and Cloward ask, "how could it have been otherwise? Important interests were at stake, and had those interests not been a profound source of contention, there would have been no need for [class] insurgency." ${ }^{32}$ Indeed, one of the greatest strengths of Poor People's Movements is the thoughtful, rational, yet firm manner in which it calls upon many students to question the class biases and assumptions they bring into the classroom-assumptions that influence and inhibit their ability to take a social movement on the terms of the people who made it. "[T]he relevant question to ask," insist Piven and Cloward, "is whether, on balance, the movement made gains or lost ground; whether it advanced the interests of working people or set back those interests." ${ }^{\prime 3}$ When framed by these questions, and discussed in the context of the southern civil rights movement's tactics of nonviolence, the tone of the conversation often shifts. The work of social change is messy and difficult. Sometimes the fact that a struggle is waged, that resistance coalesces, must itself be the only triumph of a struggle, for "[w]hat was won must be judged by what was possible." The community efforts of the Panthers would have been noteworthy had they stopped at emergency food relief, and their service work would have been subversive if their chief aim had been simply to provide needed goods and services to the urban poor. But in effect, doing for the hungry poor of the nation's urban ghettoes what the federal government claimed to be doing, and moreover encouraging the members of the community to do for themselves, constituted political work, meaningful organizing, and class mobilization for grander, if ultimately unachieved, ends. The revolution the Panthers sought was not to be, but the means by which they prepared for that revolution made clear the relevance of politics to the everyday lives of the hungry poor. This itself must be seen as a victory, for in doing so they framed hunger as an issue of power and inequitable resource distribution rather than a fleeting personal condition that beset the lazy or the unfortunate. Launched in the early years of the Nixon administration in the shadow of Johnson's grand, unrealized Great Society, Panther hunger programs called attention to the bipartisan failure to establish or maintain a defensible, humane hunger safety net. Neither Democrats nor Republicans were solely responsible but neither had the wherewithal to actually, finally tackle the problem. This lesson opens the door to potentially revealing and undoubtedly difficult discussions about how to tackle the persistence of food insecurity in the second decade of the $21^{\text {st }}$ century. 


\section{Notes}

1 Alondra Nelson previewed her research at the 2011 American Studies Association Conference in Baltimore, MD. Alondra Nelson, Body and Soul: The Black Panther Party and the Fight Against Medical Discrimination (University of Minnesota Press, 2011).

2 Frances Fox Piven and Richard A. Cloward, Poor People's Movements: Why They Succeed, How They Fail (New York: Vintage Books, 1977).

3 Kyla Wazana Tompkins, Racial Indigestion: Eating Bodies in the 19th Century (New York University, 2012), 2.

4 "To Feed Our Children," The Black Panther (26 March 1969).

5 Qtd. in "Overview: Food for Peace," U.S. Food Aid and Security Website < http://foodaid.org/food-aid-programs/food-for-peace/> (accessed 13 Feb 2012).

6 Janet Poppendieck, Breadlines Knee Deep in Wheat: Food Assistance in the Great Depression (Rutgers University Press, 1985).

7 Alison Hope Alkon and Julian Agyeman (eds.), Cultivating Food Justice: Race, Class, and Sustainability (Cambridge: Massachusetts Institute of Technology Press, 2011), 13.

8 Black Panther Party, "What We Want, What We Believe" (1966), available at http://www.blackpanther.org/TenPoint.htm (accessed 18 Oct 2013).

9 David Hilliard and Donald Weise (eds.), The Huey P. Newton Reader (New York and London: Seven Stories Press, 2002), 58.

10 The most successful of these official efforts was the 1967 passage of the Mulford Act, which prohibited the carrying of loaded firearms in public, which had been the principle Panther tactic during the early months of the Party. See Joshua Bloom and Waldo E. Martin, Jr., Black Against Empire: The History and Politics of the Black Panther Party (University of California Press, 2013), 57-61.

11 Ryan Kirkby, "'The Revolution Will Not Be Televised': Community Activism and the Black Panther Party, 1966-1971," Canadian Review of American Studies Vol. 41.1 (2011), 25, 26, 30.

12 Joshua Bloom and Waldo E. Martin, Jr., Black Against Empire: The History and Politics of the Black Panther Party (University of California Press, 2013), 393.

13 "Reform or Revolution?" The Black Panther (3 Mar 1969).

14 Qtd. in Alondra Nelson, Body and Soul: The Black Panther Party and the Fight Against Medical Discrimination (Minneapolis: University of Minnesota Press, 2011), 58.

15 Huey P. Newton, qtd. in Mumia Abu-Jamal, We Want Freedom: A Life in the Black Panther Party (Cambridge, Massachusetts: South End Press, 2004), 70.

16 Elaine Brown, A Taste of Power: A Black Woman's Story (New York: Anchor Books, 1994), 10.

17 Qtd. in Kenneth O'Reilly, "Racial Matters": The FBI's Secret File on Black America, 1960-1972 (New York: The Free Press, 1989), 302.
18 Ibid., 302-303.

19 David Hilliard, "Introduction," in David Hilliard and Donald Weise (eds.), The Huey P. Newton Reader (New York and London: Seven Stories Press, 2002), 15

20 "Capitalism Attacks Breakfast for Children," The Black Panther (20 Mar 1969), 15.

21 Interview with Bobby Seale [Section title and pg unknown], The Black Panther (3 March 1969), 43.

22 Donna Jean Murch, Living for the City: Migration, Education, and the Rise of the Black Panther Party in Oakland, California (Chapel Hill: University of North Carolina Press, 2010), 175. Panther leader Kathleen Cleaver remarked in 2010, "[With t] he kind of problems that the black community suffer-unequal levels of imprisonment, unequal levels of access to resources, poor health ...the Black Panther Party tried to model for the community some of the possible solutions that were not capitalistic-oriented, like free clinics...or 'send your children to us and we will feed them for free.' And the idea of free breakfasts is one of the legacies that's been adopted with schools now having free breakfasts. But they didn't before. The Black Panther Party was not the only organization that did it, but it was the only organization based in ghetto communities that did it." Black Power Mixtape, 1967-1975, dir. Goran Olsson (PBS, 2011); emphasis added.

23 Joshua Bloom and Waldo E. Martin, Jr., Black Against Empire: The History and Politics of the Black Panther Party (University of California Press, 2013), 312

24 Black Power Mixtape, 1967-1975, dir. Goran Olsson (PBS, 2011).

25 See Janet Poppendieck, Sweet Charity?: Emergency Food and the End of Entitlement (New York: Penguin Books, 1998). For a shorter, more condensed version of Poppendieck's argument, see Janet Poppendieck, "Want Amid Plenty: From Hunger to Inequality," in Carole Counihan and Penny Van Esterik (eds.), Food and Culture: A Reader, 3rd ed. (New York and London: Routledge, 2013), 563-571.

26 Janet Poppendieck, "Want Amid Plenty: From Hunger to Inequality," in Carole Counihan and Penny Van Esterik (eds.), Food and Culture: A Reader, 3rd ed. (New York and London: Routledge, 2013), 568.

27 Ibid., 567

28 Ibid., 569

29 Frances Fox Piven and Richard A. Cloward, Poor People's Movements: Why They Succeed, How They Fail (Vintage Books: New York, 1977, rprt 1979).

30 Frances Fox Piven and Richard A. Cloward, Poor People's Movements: Why They Succeed, How They Fail (Vintage Books: New York, 1977, rprt 1979).

31 Ibid., 3.

32 Ibid., xiii

33 Ibid., xiii.

RADICAL TEACHER 


\section{$((c))$ EY-NC-NO}

ULLS D-Sorle

This work is licensed under a Creative Commons Attribution-Noncommercial-No Derivative Works 3.0 United States License.

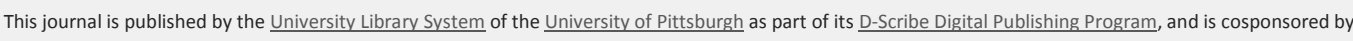
the University of Pittsburgh Press.

RADICAL TEACHER

http://radicalteacher.library.pitt.edu

No. 98 (Winter 2014)

DOI 10.5195/rt.2014.id 